\title{
PENGEMBANGAN PRODUK DAN STRATEGI PEMASARAN BUSANA BATIK BANTULAN DENGAN STILASI MOTIF ETHNO MODERN
}

\author{
Sri Wening, Enny Zuhni Khayati, Sri Emy Yuli Suprihatin \\ Fakultas Teknik, Universitas Negeri Yogyakarta \\ E-mail: riwening@yahoo.co.id
}

\begin{abstract}
Abstrak: Pengembangan Produk dan Strategi Pemasaran Busana Batik Bantulan dengan Stilasi Motif Ethno Modern. Penelitian ini bertujuan untuk: 1) mengidentifikasi permasalahan untuk mengembangkan produk dan memasarkan kain batik, 2) mengembangkan produk kain batik berpola dengan stilasi motif ethno modern untuk busana wanita, 3) mengetahui tingkat kemenarikan produk kain batik berpola dengan stilasi motif ethno modern untuk busana wanita, 4) mengembangkan pemasaran produk kain batik berpola dengan stilasi motif ethno modern untuk busana wanita. Penelitian ini menggunakan pendekatan research and development (Borg W.R., 1981). Data dikumpulkan melalui observasi partisipasi, Focus Group Discussion (FGD), angket dan wawancara kepada para pengrajin batik Giriloyo Kabupaten Bantul DIY. Data dianalisis dengan menggunakan metode kualitatif dan kuantitatif secara deskriptif. Hasil penelitian menunjukkan bahwa; (1) para pengrajin kesulitan mengembangkan kreativitas mencipta desain motif, desain produk batik dan pewarnaan untuk produk baru di luar pakem batik tulis dan memasarkan produk batik, sehingga penjualannya tidak sesuai dengan yang diharapkan karena harganya mahal dengan konsumen tertentu; (2) menghasilkan kain batik berpola dengan stilasi motif ethno modern untuk busana wanita melalui pelatihan kepada para pengrajin batik melalui tahapan: membuat buku panduan pelatihan, membuat prototype kain batik berpola dengan stilasi motif ethno modern, pelatihan pengembangan produk, uji coba pembuatan produk kain batik berpola dengan stilasi motif ethno modern untuk busana wanita oleh para pengrajin, dan menguji tingkat kemenarikan produk kain batik kepada pemerhati batik tulis; (3) dari delapan 8 desain motif kain berpola dan busana yang dibuat mendapat penilaian yang baik dari konsumen dan konsumen menyatakan tertarik baik dari segi bahan utama, corak dan warna batik, ukuran dan lokasi motif, tampilan secara keseluruhan dan panjang kain 2,5m dan 3 m; (4) strategi pemasaran dengan bentuk pameran dan fashion show secara berkala lebih meningkatkan animo masyarakat untuk mengenal lebih jauh batik Giriloyo dan memperluas segmen pasar produk kain batik bantulan berpola dengan stilasi motif ethno modern.
\end{abstract}

Kata kunci: produk batik bantulan, strategi pemasaran, stilasi motif ethno modern

\footnotetext{
Abstract: The Development of Products and Marketing Strategies of Bantulan Batik Clothing with Stylization of Modern Ethnic Motifs. This study aims to: 1) identify problems in the development of batik cloth products and the marketing, 2) develop patterned batik cloth products with stylization of modern ethnic motifs for women's clothing, 3 ) investigate the attractiveness level of patterned batik cloth products with stylization of modern ethnic motifs for women's clothing, and 4) develop marketing of patterned batik cloth products with stylization of modern ethnic motifs for women's clothing. The study employed the research and development approach (Borg, W.R., 1981). The data were collected through participant observations, Focus Group Discussion (FGD), a questionnaire, and interviews with batik craftsmen/ craftswomen in Giriloyo, Bantul Regency, Yogyakarta Special Territory. The data were descriptively analyzed by means of the qualitative and quantitative methods. The results of the study show that: (1) the craftsmen/craftswomen find it difficult
} 
to develop creativity in creating motif designs and batik product designs, to color new products other than the usual hand drawn batik, and to market batik products so that the sales are not as they expect because the prices are high for particular consumers; (2) producing patterned batik cloth with stylization of modern ethnic motifs for women's clothing is done through training for craftsmen/craftswomen with the steps of: making a training guidebook, making the prototype of patterned batik cloth with stylization of modern ethnic motifs, conducting product development training, trying out the making of patterned batik cloth with stylization of modern ethnic motifs for women's clothing by craftsmen/craftswomen, and assessing the attractiveness level of batik cloth products involving those interested in hand drawn batik; (3) the eight (8) motif designs of patterned cloth and clothing made obtain good assessment from the consumers and they are interested in the primary material, batik styles and colors, motif size and location, overall performance, and cloth lengths of $2.5 \mathrm{~m}$ and $3 \mathrm{~m}$; and (4) the marketing strategies employ regular exhibitions and fashion shows to improve society's interest in knowing Giriloyo batik further and to expand the market segment of bantulan batik cloth products with stylization of modern ethnic motifs.

Keywords: bantulan batik products, marketing strategies, stylization of modern ethnic motif

\section{PENDAHULUAN}

Dalam tata ekonomi global mulai menunjukkan kecenderungan kuat pada potensi akan kreativitas pengolahan produk-produk berbasis warisan budaya, dan batik diyakini dapat menjadi semacam deposite tambang baru untuk terus dieksplorasi. Dengan demikian batik bantulan sebagai warisan budaya bangsa perlu ditempatkan sebagai deposite, tambang baru yang harus terus digali, diolah dan dikembangkan sesuai selera konsumen agar dapat mendatangkan kesejahteraan bagi masyarakat atau bangsa Indonesia.

Dusun Giriloyo Kalurahan Wukirsari Kecamatan Imogiri Kabupaten Bantul Daerah Istimewa Yogyakarta merupakan dusun kecil yang terletak di $17 \mathrm{Km}$ sebelah timur Kota Yogyakarta. Dusun tersebut merupakan salah satu dusun yang masyarakatnya, terutama para perempuannya memiliki ketrampilan membatik yang sangat potensial. Ketrampilan tersebut mereka miliki secara turun temurun. Sejak Sultan Agung wafat dan dimakamkan di daerah Imogiri. Interaksi Kerabat Keraton dengan masyarakat setempat memberikan mereka suatu ilmu baru yaitu membatik dengan canting, sejak itulah batik dijadikan sumber penghasilan masyarakat setempat sampai sekarang, meskipun mereka hanya mampu sebagai buruh batik, dan belum mampu untuk mengembangkan tekniknya, motifnya maupun pewarnaannya.

Peristiwa gempa bumi dengan kekuatan 6,9 skala Richter yang terjadi pada tanggal 27 Mei 2006 telah menghancurkan tempat dan peralatan membatik mereka. Sejak itu aktifitas membatik secara otomatis menjadi lumpuh, mereka banyak yang kehilangan sandaran ekonomi keluarga, akibatnya banyak kaum muda daerah itu meninggalkan kampungnya untuk alih ketrampilan ke Kota-kota lain. Dengan demikian perlu memberikan motivasi dan spirit agar mereka bangkit kembali untuk terus melestarikan tradisi membatik sebagai warisan leluhur dan seni budaya bangsa yang sangat berharga dan perlu dilestarikan sehingga dapat dijadikan sandaran hidup yang mensejahterakan keluarganya.

Tahun 2007 masyarakat dusun Giriloyo berangsur-angsur mulai berbenah diri agar terus dapat memanfaatkan ketrampilan membatiknya dengan peralatan seadanya agar tetap dapat menyalurkan bakat, hoby dan ketrampilan membatiknya sekaligus dapat terus melestarikan seni membatik. 
Keterbatasan pengetahuan, teknik, pengembangan motif dan pewarnaan menjadi salah satu faktor kurang dapat berkembangnya produk batik Giriloyo. Oleh karena itulah merekan perlu diberikan sport, bantuan, dan bimbingan yang sungguh- sungguh, agar dapat memenangkan persaingan global saat ini. Dengan demikian Penelitian tentang Pengembangan produk busana batik Bantulan dengan stilasi motif Ethnomodern dan strategi pemasarannya menjadi sangat penting untuk dilaksanakan secara mendalam. Riset ini dilakukan bertolak dari perlu dicarinya Peluang bisnis sektor industri kreatif yang secara komparatif dan kompetitif mampu memanfaatkan Sumber Daya Alam atau potensi daerah di Indonesia. Sub bidang fashion dan cinderamata dari bahan dasar batik bantulan yang merupakan unggulan daerah Bantul Yogyakarta harus mampu mencari terobosan karena batik bantulan masih terbatas pangsa pasarnya.

Alasan utama yang mendasar Batik Bantulan menjadi produk unggulan, pertama Sumber Daya Manusia yang memiliki kemampuan dan ketrampilan membatik di daerah Bantul cukup banyak. Kedua batik bantulan merupakan komuditas dengan nilai budaya dan nilai ekonomi yang tinggi. Ketiga Kontribusi subbidang fashion dengan bahan dasar batik menunjukkan kecenderungan meningkat. Keempat Yogyakarta merupakan Daerah Tujuan Wisata sehingga sangat membutuhkan dukungan komuditi cinderamata yang mampu memikat wisatawan untuk senang dan tinggal lebih lama di kota Yogyakarta, dan mengesankan. Disisi lain perkembangan kawasan Asia Pasifik sebagai masa depan dunia merupakan potensi pasar bagi produk fashion dan handycraft dari bahan dasar batik Indonesia, yang permintaannya menunjukkan peningkatan 1,7 \% per tahun. Hambatan-hambatan yang dirasakan dalam pemasaran batik bantulan saat ini antara lain motif batiknya yang masih tradisional, dengan warna-warna yang kurang bervariasi sehingga kesannya monoton, cepat membosankan, kuno, dan tua. Selain itu desain busana yang dipro- duksi mengalami kejenuhan dan kurang mengikuti selera pasar saat ini.

Untuk mencipta motif batik bantulan yang khas dan memikat dapat dilakukan dengan beberapa cara, salah satunya dengan stilasi motif modern, memadukan motif tradisional dan modern, atau kolaborasi gaya motifgeometris dan non geometris, sehingga diperoleh motif indah yang semiotik dan memikat konsumen. Dengan demikian busana batik tetap dicintai dari semua kalangan dan usia secara terus menerus dan menjadi produk yang diunggulkan untuk mengembangkan potensi daerah sekaligus menyediakan lapangan pekerjaan bagi masyarakat setempat. Motif batik tradisional merupakan hasil seni budaya nenek moyang yang sangat adiluhung karena setiap unsurnya memiliki filosofi yang bermakna sangat dalam bagi kehidupan manusia, pemahaman makna simbolik atau sering disebut dengan semiotik ini sudah kurang difahami oleh generasi muda, sehingga perlu adanya solusi yang menarik untuk semua kalangan.

Salah satu upaya yang prospektif untuk menanggulangi masalah ini adalah mengajak dan melatih para pengrajin batik atau busana berbahan dasar batik bantulan untuk terus mengembangkan produksi batik atau busana dengan bahan dasar batik bantulan berpola yang berkarakter Ethnomodern. Salah satu strategi dan upaya untuk memperluas pemasaran dan sekaligus mendukung pelestarian warisan seni budaya bangsa termasuk kerajinan batik bantulan Giriloyo, dan untuk meningkatkan pendapatan pengrajin batik bantulan Giriloyo, maka penelitian tentang pengembangan produk dan strategi pemasaran kain batik bantulan Giriloyo dengan stilasi ethno modern sangat perlu dilakukan. Permasalahan dalam penelitian ini adalah 1) permasalahan apa sajakah yang dihadapi untuk mengembangkan produk dan memasarkan kain batik, 2) bagaimanakah mengembangkan produk kain batik berpola dengan stilasi motif ethno modern untuk busana wanita, 3) sejauhmana tingkat kemenarikan produk kain batik berpola dengan stilasi motif ethno modern 
untuk busana wanita, 4) bagaimanakah mengembangkan pemasaran produk kain batik berpola dengan stilasi motif ethno modern untuk busana wanita.

Adapun tujuan dari penelitian ini adalah untuk 1) mengidentifikasi permasalahan untuk mengembangkan produk dan memasarkan kain batik, 2) mengembangkan produk kain batik berpola dengan stilasi motif ethno modern untuk busana wanita, 3) mengetahui tingkat kemenarikan produk kain batik berpola dengan stilasi motif ethno modern untuk busana wanita, dan 4) mengembangkan pemasaran produk kain batik berpola dengan stilasi motif ethno modern untuk busana wanita

Motif Batik secara garis besar terdapat dua golongan motif batik, yaitu motif geometris dan non geometris, Sewan $\mathrm{Su}$ santo (1980: 212) mengadakan pembagian motif menjadi dua bagian utama yaitu (1) ornamen motif batik yang dibedakan menjadi ornamen utama dan ornament tambahan, (2) isen motif batik berupa titik-titik, garisgaris dan gabungan titik dan garis, yang berfungsi untuk mengisi ornamen-ornamen dati motif utama atau bidang diantara ornamen-ornamen tersebut. Isen ini diberi nama cecek, cecek pitu, cecek sawut, cacah gori, dan lain sebagainya.

Karakteristik Motif Gaya Tradisional susunan motifnya terikat oleh suatu ikatan tertentu dengan isen-isen tertentu dan memiliki filosofi atau kebermaknaan yang sangat tinggi, sedangkan motif gaya modern cirinya tidak beraturan, dan tidak berulang tetapi tetap dalam tata hias yang indah, dinamis dan menggambarkan fenomena masa kini . Awalnya, batik memiliki ragam corak dan warna yang terbatas, dan beberapa motif atau ragam corak hanya boleh dipakai oleh kalangan tertentu. Namun batik pesisir menyerap berbagai pengaruh luar, seperti para pedagang asing. Warna-warna cerah seperti merah dipopulerkan oleh orang Tionghoa, yang juga mempopulerkan corak phoenix.

Motif Batik Ethno Modern merupakan jenis motif batik modern tetapi memiliki sentuhan motif klasik tradisional/Etnik nusantara maupun dunia, sehingga memiliki kesan unik, lebih dinamis dan global. Ciri lain motif batik Ethno modern adalah memiliki ornamen modern berupa flora maupun fauna ataupun benda yang lain yang memiliki garis motif lebih bebas, dipadu dengan isen-isen yang tradisional. Kadangkadang motifnya termasuk tradisional tetapi warnanya menggunakan warna-warna yang bergaya modern atau populer.

Untuk memperoleh hasil rancangan motif yang indah dan memiliki efek tertentu, maka dalam merangkai atau menyusun unsur-unsur desainnya (garis, arah, tekstur, value, warna, dan bentuk) dapat menggunakan prinsip-prinsip desain (keserasian, proporsional, satu kesatuan, keseimbangann, aksen/centre of interest, dan Irama). Untuk penerapan prinsip tersebut dapat menggunakan kosep kombinasi atau paduan prinsip satu dengan prinsip yang lainnya. Suatu hukum kombinasi, sehingga penerapan prinsip satu dengan prinsip lainnya dapat dipadupadankan Prinsip desain merupakan. Dasar memadu padankan tersebut ada tiga cara yaitu: 1) Teknik pengulangan, (repetition) suatu unsur desain dapat diulang-ulang beberapa kali bahkan di beberapa tempat, 2) Teknik keserasian atau harmoni, yang mana unsur satu dengan unsur yang lainnya dikombinasikan dengan baik dan serasi, 3) Teknik kontras atau perbedaan, suatu perbedaan tidak selamanya menimbulkan sesuatu yang tidak baik, tetapi perbedaan itu juga dapat menimbulkan sesuatu yang indah dan menguntungkan.

Khusus untuk motif ethno modern prinsip simplicity, inovatip, dan bervariasi sangat dianjurkan, sehingga tidak membosankan, lebih menarik, dan dapat menyesuaikan dengan kebutuhan zaman untuk segala usia dan untuk seluruh lapisan masyarakat dunia. Untuk mencipta desain motif batik ethno modern yang indah dan harmonis, yang perlu diperhatikan adalah: (a) memperhatikan tujuan pembuatan motif (misalnya untuk gaun wanita dewasa), (b) memilih sumber ide (misalnya rumpun bambu), (c) 
mempelajari secara mendalam sumber ide yang akan dikembangkan (mencermati detil-detilnya, warna, sifat, makna perlambang), (d) menelaah bentuk bidang yang akan diberi motif (menentukan lokasi motif, menentukan ukurannya), (e) menentukan pola motif (bentuk pola motif yang sesuai dengan bidang yang tersedia).

Transformasi dapat terlihat dengan adanya perubahan bentuk sebagai akibat dari perubahan konsep desain motif. Suatu arus desain yang terkait kebutuhan akan identitas desain baru. Pengembangan bentuk dan pola motif ragam hias atau ornamen, dan isen-isen motif batik baru, dapat menciptakan paduan-paduan motif yang kreatif, bentuk dan garis motif yang bebas terbuka, dan idaman estetika spasial yang baru.

Kain batik adalah kain atau tekstil yang corak motifnya dibuat dengan proses pelekatan lilin (malam batik), kemudian pewarnaannya melalui proses pencelupan zat warna. Zat warna yang dipergunakan dapat berupa zat warna dari bahan alam seperti sari kayu jolawe, kayu mahoni, maupun kayu nangkan, daun mangga, daun oncit, daun kangkung, dan lain sebagainya

Kain batik yang motifnya tidak penuh, dan ditempatkan pada lokasi-lokasi tertentu saja berdasarkan pola bagian-bagian busananya, sering disebut dengan Bahan Batik Berpola. Bagian-bagian busana yang biasanya diberi motif ataupun hiasan contohnya: Bagian garis leher, pola lengan, rok , krah, pola badan muka dan badan belakang, dan lain sebagainya. Jadi kain batik berpola pada dasarnya adalah kain batik yang memiliki garis-garis pola bagian-bagian busana yang tetata secara efisien, sehingga tidak perlu repot-repot lagi merancang tataletak pola bagian-bagian busana di atas kain batik yang hendak dipotong. (Enny Zuhni Khayati, 2009)

Menurut M. Hasanudin (2001: 17-18) gambaran yang paling sederhana menganai pencelupan zat warna alam adalah memasukkan bahan tekstil (benang atau kain) ke dalam larutan zat, setelah zat warna masuk, bahan tersebut diambil, dikeringkan, difiksasi, lalu dicuci dan setelah pencucian selesai bahan tekstil manjadi berwarna sesuai dengan warna yang dikehendaki. Tahapan Pencelupan Zat Warna Alam adalah: 1) Membuat larutan zat warna (bahan baku zat warna alam direbus), 2) Mencelup atau memasukkan bahan ke dalam larutan zat warna, 3) Fiksasi atau memperkuat reaksi dan warna bangkit, 4) Terjadi reaksi antara serat dan zat warna.

Perkembangan dunia industry menuntut desain yang selalu baru dan kreatif, namun tentu yang dilihat konsumen bukan saja desain, melainkan juga fungsi dan estetika yang diberikan. Konsumen selalu menunggu apa inovasi dari desain yang selanjutnya akan dilakukan. Perbaikan secara terus menerus membutuhkan pemikiran yang matang, sehingga diperlukan perencanaan dalam perancangan produk. Menurut Tontowi perancangan produk dapat dilakukan mengikuti alur sebagai berikut:

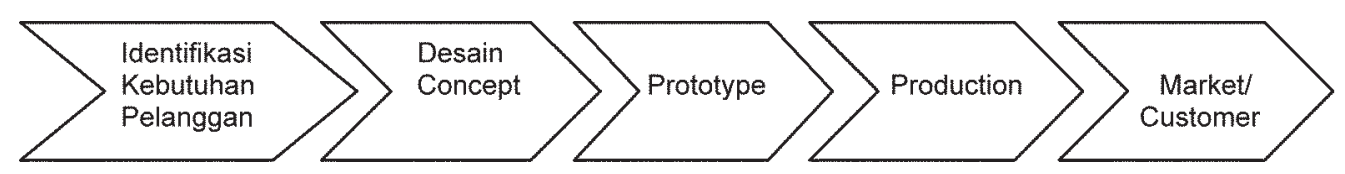

Setelah rancangan selesai dibuat dilanjutkan dengan membuat prototype yang diuji kelayakannya. Setelah mendapat rekomendasi kelayakan dari beberapa pakar dapat diproduksi yang selanjutnya dapat dilempar ke pasar. Strategi pemasaran merupakan alat fundamental yang direncanakan untuk mencapai tujuan perusahaan dengan mengembangkan keunggulan bersaing yang berkesinambungan melalui pasar yang dituju. Strategi pemasaran yang dipilih harus dapat memberikan arah pada elemen-elemen pemasaran. Ada 4 elemen penting dalam strategi pemasaran dan promosi yang perlu diperhatikan yaitu: 1) Tampilan produk yang menarik, 2) Kemasan produk yang aman dan 
menarik, 3) memilih metode pemasaran, 4) Sikap wirausaha terhadap konsumen: 3S1H Senyum, Sapa, Sabar, Harapan. Proses strategi pemasaran mengikuti langkahlangkah sebagai berikut: analisis situasi, desain strategi pemasaran, pengembangan program pemasaran, dan implementasi dan evaluasi strategi pemasaran (Philip KotlerGary Armstrong, 1997).

Promosi sendiri merupakan aktivitas pemasaran yang berusaha menyebarkan informasi,mempengaruhi/membujuk, dan / atau mengingatkan pasar sasaran atas perusahaan danproduknya agar bersedia menerima, membeli, dan loyal pada produk yang ditawarkan perusahaan. Dalam melakukan promosi perusahaan dapat memilih bauran promosi sesuai tujuan yang diharapkan. Bauran promosi antara lain: 1) Personal Selling, 2) Mass selling, 3) Promosi Penjualan, 4) Public Relation, 5) Direct market.

Bentuk promosi penjualan yang banyak dilakukan adalah melakukan pameran produk dan pagelaran busana atau fashion show, karena sifat-sifat yang terkandung dalam promosi penjualan adalah komunikasi, insentif, undangan. Tujuan pameran biasanya untuk memperkenalkan produk baru ide baru agar mendapat dukungan dari masyarakat. Dukungan dari masyarakatakan berpengaruh besar pada proses selanjutnya. Pagelaran busana adalah suatu pameran mode untuk busana yang bertujuan untuk memamerkan rancangan busana atau abahan busana. Tujuan pageran busana adalah: 1) member hiburan, 2) mencari dana untuk suatu kegiatan, 3) untuk mempromosi suatu produk fashion. Publik Relation merupakan komunikasi menyeluruh dari suatu perusahaan untuk mempengaruhi persepsi, opini, keyakinan, dan sikap berbagai kelompok perusahaan.

Kepuasan konsumen terhadap produk batik adalah perasaan senang, dan lega karena kualitas hasil produk batik yang berwujud kain sebagai bahan busana wanita sama atau lebih dari apa yang dibutuhkan, diinginkan dan diharapkan, Kepuasan konsumen terhadap produk batik sangat tergantung kualitasnya, dalam halini meliputi: pemilihan bahan baku, motif atau ragam hias/ornamennya, teknik pembatikan dan penyajian secara keseluruhannya (total look). Produk batik yang berkualitas tinggi akan memuaskan konsumen. Kualitas tersebut antara lain dapat dilihat dari sisi: 1) Kain Batik yang dikerjakan dengan rapi dan bersih, 2) Mempergunakan bahan pokok dan pelengkap yang berkualitas tinggi, 3) Motif-motif batik dengan desain dan konsep yang baik dan menarik, 4) Hasil pewarnaan yang tidak luntur, dan rata, dan 5) Pengemasan yang rapi, menarik dan mudah membawanya.

\section{METODE}

Penelitian ini menggunakan prosedur Research and Development yang pokokpokok kegiatannya diambil dari buku Educational Research (Borg and Gall, 1998), dengan mengikuti tahap-tahap penelitian sebagai berikut: melakukan base line study untuk memotret permasalahan pengebangan produk batik untuk meningkatkan omzet penjualan, merancang prototype kain batik berpola, menyusun dan menerapkan model pendidikan dan pelatihan motif ethno modern, menyusun dan menerapkan program pemasaran produk, mengevaluasi hasil terhadap kemenarikan dan kepuasan produk batik berpola dengan stilasi motif ethno modern.

Subyek penelitian ini diambil secara purposive berdasarkan peranannya dalam kegiatan penelitian. Secara keseluruhan subyek yang dilibatkan dalam penelitian ini terdiri dari: pengurus paguyupan batik Giriloyo, anggota paguyupan batik Giriloyo, dan konsumen.

Metode pengumpulan data dibagi menjadi dua kategori yaitu metode pengumpulan data kualitatif dan kuantitatif. Metode pengumpulan data kualitatif dilakukan dengan metode observasi dan curah pendapat (brainstorming) dengan (FGD). Metode pengumpulan data kuantitatif dilakukan menggunakan kuesioner dan dokumentasi. 
Analisis data dilakukan dengan cara deskriptif kuantitatif dan kualitatif. Analisis data dilakukan pada setiap tahap kegiatan pengumpulan data. Hasil analisis selama proses pengembangan digunakan untuk perbaikan dan perencanaan tindakan tahap kegiatan berikutnya.

\section{HASIL DAN PEMBAHASAN}

1. Mengidentifikasi permasalahan untuk mengembangkan produk dan memasarkan kain batik

Berdasarkan informasi yang diperoleh peneliti bahwa bahwa $100 \%$ pengrajin batik di wilayah tersebut menyatakan sangat membutuhkan pelatihan pengembangan kain batik berpola dengan stilasi motif Ethnomodern, dengan pewarnaan alam, yang dilengkapi dengan buku panduan praktis. Pengembangan kreatifitas dalam mencipta motif batik juga sangat dibutuhkan. Pelatihan strategi pemasaran produk kain batik juga sangat dibutuhkan terbukti $80 \%$ pengurus paguyupan menyatakan sangat dibutuhkan dan 20\% menyatakan dibutuhkan. Sedangkan menurut pernyataan responden (100\%) untuk saat ini study banding pada pengrajin sejenis dan membentuk koperasi tidak dibutuhkan, karena sudah dibentuk.

2. Mengembangkan produk kain batik berpola dengan stilasi motif ethno modern untuk busana wanita

Kegiatan perancangan kain batik berpola dengan stilasi motif ethno modern meliputi tahapan kegiatan yang cukup panjang dan kompleks. Langkah-langkah yang dilakukan adalah: a) analisis kebutuhan, b) penyusunan dan validasi buku panduan praktis pengembangan motif ethno modern tentang: konsep dasar desain ragam hias batik, unsur-unsur dan prinsip desain ragam hias batik, pola motif batik, penciptaan motif batik, pengembangan Sumber ide, langkahlangkah penciptaan motif batik dengan Stilasi Ethnomodern, penempatan motif pada bagian pola busana wanita, dan contoh-contoh motif ethnomodern, c) pembuatan prototype kain batik berpola, sesuai dengan hasil FGD melalui curah pendapat antara peneliti dengan para pengrajin batik Giriloyo, pakar bidang batik. Menghasilkan 8 variasi desain prototype kain batik Bantulan berpola dengan stilasi motif ethnomodern untuk busana wanita berbahan mori Primisima merek Kereta Kencana lebar $105 \mathrm{~cm}$, panjang dan 2,5 $\mathrm{m}$ dan $3 \mathrm{~m}$ yang sesuai dengan trend masa kini, d) melakukan kegiatan pendidikan dan pelatihan, e) melakukan uji coba hasil pembuatan kain batik berpola untuk mengetahui tingkat kemenarikkan dan kepuasan konsumen, f) melakukan program pameran dan fashion show untuk perluasan pemasaran hasil pendidikan dan pelatihan.

Berdasarkan data hasil penelitian, para peserta memberikan penilaian baik (4) dan sangat baik ( 5) terhadap penyelenggaraan pendidikan dan pelatihan yang diberikan hal ini menunjukkan bahwa penyelenggaraan pelatihan dapat berjalan dengan baik dan lancar dan sesuai dengan yang dibutuhkan peserta, baik dari segi fasilitator atau Instruktur, proses pelaksanaan, maupun proram pelatihannya. Ditemukan pula berdasarkan observasi terjadi Perubahan Perilaku Pengrajin Batik Pasca Pelatihan, setelah diberikan materi tentang konsep dan teknik transformasi motif batik, dan memiliki motivasi untuk mau dan berani mengembangkan kreatifitasnya dalam merancang kain batik berpola dengan stilasi motif ethno modern. Mereka sangat antusias mencipta motif ethno modern dan lebih berani berkreasi dengan memanfaatkan sumber ide alam sekitar dan benda lainnya, meskipun masih dirasa kurang menyukai tantangan, terbukti bila disarankan untuk memanfaatkan sumber ide yang selain tumbuhan masih sering menolak. 
3. Kemenarikan produk kain batik berpola dengan stilasi motif ethno modern untuk busana wanita

Dari delapan (8) desain motif dan busana yang dibuat terbukti mendapat penilaian yang baik dari konsumen dan konsumen menyatakan tertarik baik dari segi bahan utama, corak dan warna batik, ukuran dan lokasi motif, tampilan secara keseluruhan dan panjang kain yang ditawarkan yakni 2,5m dan $3 \mathrm{~m}$. Ini berarti kedelapan desain kain batik yang dibuat layak untuk diproduksi, ini dapat dibuktikan dari data pada tabel 5 sampai 12 berikut ini:

Dalam uji coba pelaksanaan pameran dilakukan uji kepuasan konsumen pada produk kain batik Bantulan berpola de-

Tabel 5. Distribusi Frekuensi Ketertarikan Konsumen Pada Desain A

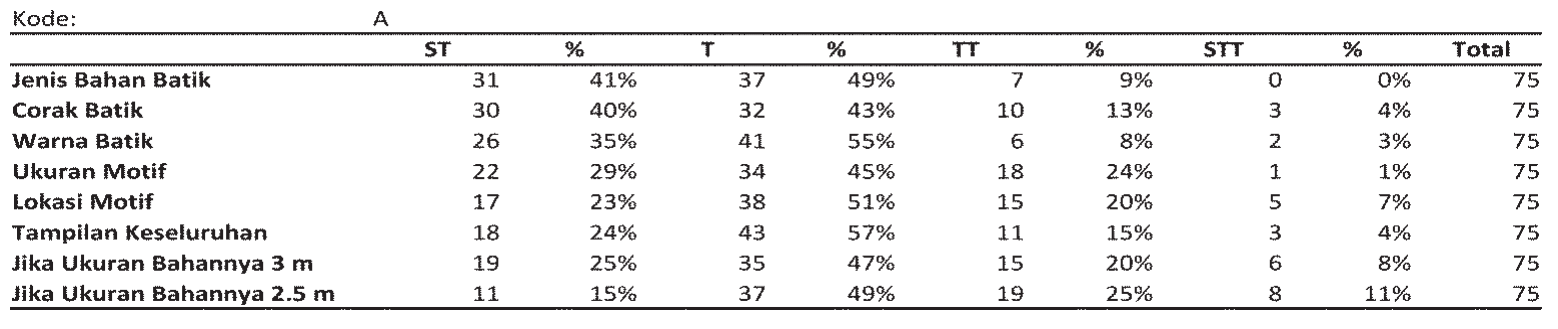

Tabel 6. Distribusi Frekuensi Ketertarikan Konsumen Pada Desain B

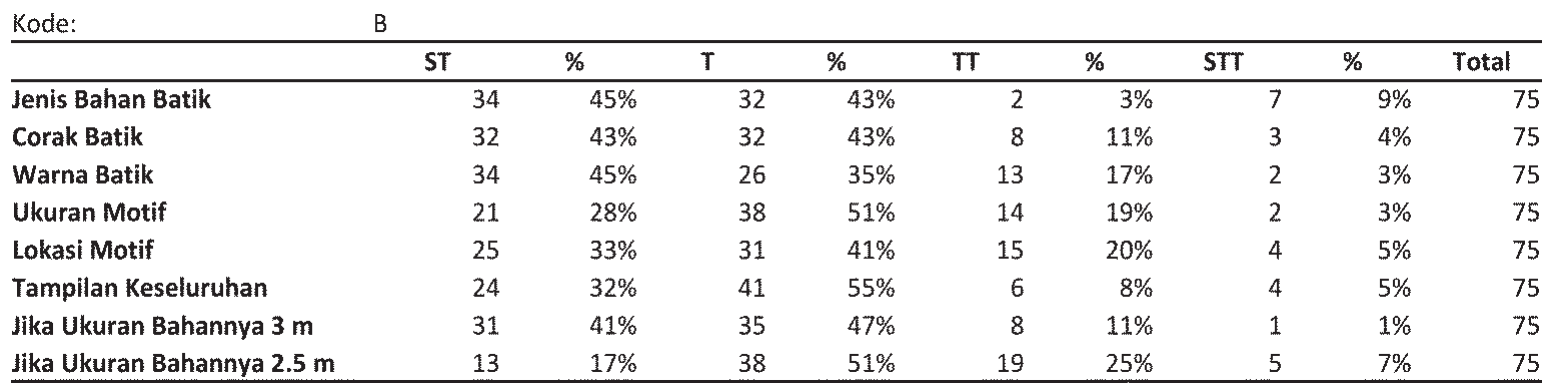

Tabel 7. Distribusi Frekuensi Ketertarikan Konsumen Pada Desain C

\begin{tabular}{|c|c|c|c|c|c|c|c|c|c|}
\hline & & & & & & & & & \\
\hline Jenis Bahan Batik & 24 & $32 \%$ & 36 & $48 \%$ & 14 & $19 \%$ & 1 & $1 \%$ & 75 \\
\hline Corak Batik & 20 & $27 \%$ & 33 & $44 \%$ & 22 & $29 \%$ & 0 & $0 \%$ & 75 \\
\hline Warna Batik & 16 & $21 \%$ & 27 & $36 \%$ & 29 & $39 \%$ & 3 & $4 \%$ & 75 \\
\hline Ukuran Motif & 12 & $16 \%$ & 38 & $51 \%$ & 24 & $32 \%$ & 1 & $1 \%$ & 75 \\
\hline Lokasi Motif & 13 & $17 \%$ & 34 & $45 \%$ & 27 & $36 \%$ & 1 & $1 \%$ & 75 \\
\hline Tampilan Keseluruhan & 13 & $17 \%$ & 39 & $52 \%$ & 22 & $29 \%$ & 1 & $1 \%$ & 75 \\
\hline Jika Ukuran Bahannya $3 \mathrm{~m}$ & 21 & $28 \%$ & 44 & $59 \%$ & 9 & $12 \%$ & 1 & $1 \%$ & 75 \\
\hline Jika Ukuran Bahannya $2.5 \mathrm{~m}$ & 13 & $17 \%$ & 34 & $45 \%$ & 26 & $35 \%$ & 2 & $3 \%$ & 75 \\
\hline
\end{tabular}

Tabel 8. Distribusi Frekuensi Ketertarikan Konsumen Pada Desain D

\begin{tabular}{|c|c|c|c|c|c|c|c|c|c|}
\hline & ST & $\%$ & $T$ & $\%$ & $T T$ & $\%$ & STT & $\%$ & Total \\
\hline Jenis Bahan Batik & 23 & $31 \%$ & 42 & $56 \%$ & 9 & $12 \%$ & 1 & $1 \%$ & 75 \\
\hline Corak Batik & 13 & $17 \%$ & 48 & $64 \%$ & 12 & $16 \%$ & 2 & $3 \%$ & 75 \\
\hline Warna Batik & 13 & $17 \%$ & 47 & $63 \%$ & 14 & $19 \%$ & 1 & $1 \%$ & 75 \\
\hline Ukuran Motif & 13 & $17 \%$ & 40 & $53 \%$ & 19 & $25 \%$ & 3 & $4 \%$ & 75 \\
\hline Lokasi Motif & 8 & $11 \%$ & 40 & $53 \%$ & 26 & $35 \%$ & 1 & $1 \%$ & 75 \\
\hline Tampilan Keseluruhan & 10 & $13 \%$ & 46 & $61 \%$ & 18 & $24 \%$ & 1 & $1 \%$ & 75 \\
\hline Jika Ukuran Bahannya 3 m & 15 & $20 \%$ & 47 & $63 \%$ & 10 & $13 \%$ & 3 & $4 \%$ & 75 \\
\hline Jika Ukuran Bahannya $2.5 \mathrm{~m}$ & 15 & $20 \%$ & 37 & $49 \%$ & 22 & $29 \%$ & 1 & $1 \%$ & 75 \\
\hline
\end{tabular}


Tabel 9. Distribusi Frekuensi Ketertarikan Konsumen Pada Desain E

\begin{tabular}{|c|c|c|c|c|c|c|c|c|c|}
\hline & ST & $\%$ & $T$ & $\%$ & $\pi$ & $\%$ & STT & $\%$ & Total \\
\hline Jenis Bahan Batik & 23 & $31 \%$ & 44 & $59 \%$ & 7 & $9 \%$ & 1 & $1 \%$ & 75 \\
\hline Corak Batik & 16 & $21 \%$ & 38 & $51 \%$ & 20 & $27 \%$ & 1 & $1 \%$ & 75 \\
\hline Warna Batik & 11 & $15 \%$ & 45 & $60 \%$ & 18 & $24 \%$ & 1 & $1 \%$ & 75 \\
\hline Ukuran Motif & 12 & $16 \%$ & 42 & $56 \%$ & 19 & $25 \%$ & 2 & $3 \%$ & 75 \\
\hline Lokasi Motif & 11 & $15 \%$ & 47 & $63 \%$ & 16 & $21 \%$ & 1 & $1 \%$ & 75 \\
\hline Tampilan Keseluruhan & 13 & $17 \%$ & 42 & $56 \%$ & 19 & $25 \%$ & 1 & $1 \%$ & 75 \\
\hline Jika Ukuran Bahannya $3 \mathrm{~m}$ & 13 & $17 \%$ & 48 & $64 \%$ & 13 & $17 \%$ & 1 & $1 \%$ & 75 \\
\hline Jika Ukuran Bahannya $2.5 \mathrm{~m}$ & 10 & $13 \%$ & 36 & $48 \%$ & 25 & $33 \%$ & 4 & $5 \%$ & 75 \\
\hline
\end{tabular}

Tabel 10. Distribusi Frekuensi Ketertarikan Konsumen Pada Desain F

\begin{tabular}{|c|c|c|c|c|c|c|c|c|c|}
\hline Jenis Bahan Batik & 37 & $49 \%$ & 31 & $41 \%$ & 2 & $3 \%$ & 5 & $7 \%$ & 75 \\
\hline Corak Batik & 27 & $36 \%$ & 44 & $59 \%$ & 2 & $3 \%$ & 2 & $3 \%$ & 75 \\
\hline Warna Batik & 17 & $23 \%$ & 35 & $47 \%$ & 19 & $25 \%$ & 4 & $5 \%$ & 75 \\
\hline Ukuran Motif & 14 & $19 \%$ & 38 & $51 \%$ & 22 & $29 \%$ & 1 & $1 \%$ & 75 \\
\hline Lokasi Motif & 14 & $19 \%$ & 30 & $40 \%$ & 28 & $37 \%$ & 3 & $4 \%$ & 75 \\
\hline Tampilan Keseluruhan & 13 & $17 \%$ & 46 & $61 \%$ & 14 & $19 \%$ & 2 & $3 \%$ & 75 \\
\hline Jika Ukuran Bahannya 3 m & 25 & $33 \%$ & 34 & $45 \%$ & 15 & $20 \%$ & 1 & $1 \%$ & 75 \\
\hline Jika Ukuran Bahannya $2.5 \mathrm{~m}$ & 16 & $21 \%$ & 36 & $48 \%$ & 22 & $29 \%$ & 1 & $1 \%$ & 75 \\
\hline
\end{tabular}

Tabel 11. Distribusi Frekuensi Ketertarikan Konsumen Pada Desain A1

\begin{tabular}{|c|c|c|c|c|c|c|c|c|c|}
\hline & ST & $\%$ & $T$ & $\%$ & $\pi$ & $\%$ & STT & $\%$ & Total \\
\hline Jenis Bahan Batik & 34 & $45 \%$ & 27 & $36 \%$ & 9 & $12 \%$ & 5 & $7 \%$ & 75 \\
\hline Corak Batik & 23 & $31 \%$ & 40 & $53 \%$ & 8 & $11 \%$ & 4 & $5 \%$ & 75 \\
\hline Warna Batik & 21 & $28 \%$ & 45 & $60 \%$ & 9 & $12 \%$ & 0 & $0 \%$ & 75 \\
\hline Ukuran Motif & 20 & $27 \%$ & 34 & $45 \%$ & 16 & $21 \%$ & 5 & $7 \%$ & 75 \\
\hline Lokasi Motif & 16 & $21 \%$ & 38 & $51 \%$ & 18 & $24 \%$ & 3 & $4 \%$ & 75 \\
\hline Tampilan Keseluruhan & 19 & $25 \%$ & 44 & $59 \%$ & 8 & $11 \%$ & 4 & $5 \%$ & 75 \\
\hline Jika Ukuran Bahannya 3 m & 17 & $23 \%$ & 49 & $65 \%$ & 4 & $5 \%$ & 5 & $7 \%$ & 75 \\
\hline Jika Ukuran Bahannya $2.5 \mathrm{~m}$ & 21 & $28 \%$ & 29 & $39 \%$ & 24 & $32 \%$ & 1 & $1 \%$ & 75 \\
\hline
\end{tabular}

Tabel 12. Distribusi Frekuensi Ketertarikan Konsumen Pada Desain B1

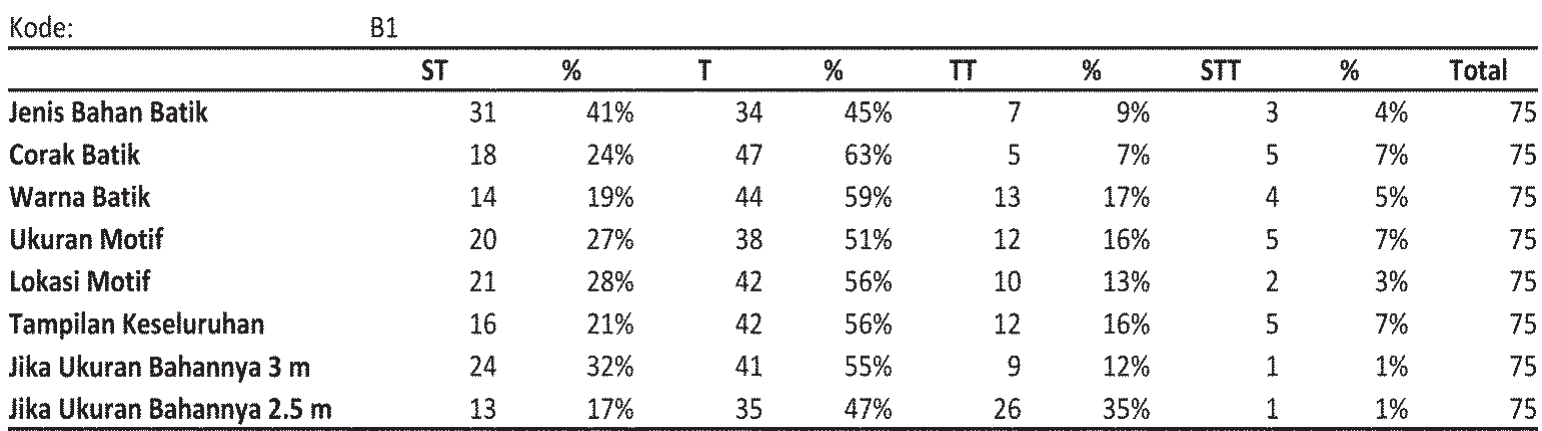

ngan stilasi motif ethno modern yang dipamerkan pada Imogiri Expo tahun 2009 (responden adalah konsumen yang membeli kain batik di Imogiri Ekspo 2009, jumlah konsumen 50 orang responden).

4. Mengembangkan pemasaran produk kain batik berpola dengan stilasi motif ethno modern untuk busana wanita
Berdasarkan hasil pengumpulan data pada peserta Diklat pengembangan produk batik bantulan berpola dengan stilasi motif ethno modern sebagian besar menghendaki untuk pengembangan pemasaran hasi produk melalui cara pameran dan peragaan busana. Mereka beralasan bahan dengan cara peragaan 
pengenalan hasil produk batik belum pernah mereka lakukan. Kemudian disepakati untuk promosi produk batik bantulan berpola dengan stilasi motif ethno modern ini ditentukan mengikuti pameran yang dapat mendatangkan pengunjung dan prospektif yaitu pameran produk unggulan daerah Bantul yang terkemas dalam kegiatan Imogiri Expo. Selain itu juga menyelenggarakan fashion show yang menampilkan produk batik bantulan berpola dengan stilasi ethno modern, fashion show ini diselenggarakan menjelang hari Raya Idul Fitri agar dapat mendatangkan pengunjung lebih banyak.dan bekerja sama dengan penyelenggaraan Jurusan Pendidikan Teknik Boga dan Busna (PTBB) Fakultas Teknik Universitas Negeri Yogyakarta.

Kualitas kain batik dapat dinilai dari pemilihan bahan baku, motif batik, teknik pembatikan dan pewarnaan, penyajian produk dan kemasan maupun harga penjualan batiknya. Aspek-aspek inilah yang selalu harus mendapat perhatian pengrajin batik, jika ingin produksi batiknya selalu menarik dan memuaskan konsumen. Dulu batik tulis dengan motif tradisional yang sakral hanya dikonsumsi oleh kalangan tertentu saja (bangsawan dan orang yang berduit) karena harga batik tulis sungguh sangat mahal. Seiring dengan berkembangnya ilmu pengetahuan, teknologi dan komunikasi serta budaya masyarakat saat ini maka Kebutuhan masyarakat akan kain batik juga mengalami peningkatan, baik darisisi fungsi maupun dari segi estetisnya, Oleh karena itu dibutuhkan variasi-variasi,dan inovasi- inovasi baik dari sisi motif dan pewarnaannya.

Produk batik dengan motif tradidional biasanya memiliki garis motif yang harus mengikuti tatanan tertentu karena sarat makna, sangat anggun, elegan, dan pewarnaan yang berkesan etnik, tua dan monoton, sehingga akan memberi kesan membosankan dan hanya dapat dikenakan pada kesempatan yang resmi sifatnya. Sedangkan motif dan pewarnaan yang lebih modern biasanya memiliki garis-garis dan sentuhan warna yang lebih bebas dan lebih variatif, memiliki kesan lebih dinamis, simple, dan luwes sehingga dapat dikenakan untuk berbagai kesempatan dan berbagai kalangan dan usia. Melestarikan yang tradisional tetapi dapat menembus selera konsumen masa kini yang sangat global, dirasa sangat sesuai untuk mengembangkan produksi batik bantulan, dengan Batik berpola menggunakan stilasi motif Ethnomodern dengan warna-warna yang lebih bervariasi. Dengan karakter motif ethnomodern yang ditata hanya pada pola bagian-bagian busana tertentu seperti bagian leher, lengan, dada, punggung, dan rok bagian bawah maka tidak semua permukaan kain dibatik, dengan demikian akan lebih efisien dalam segi tenaga dan waktu, selanjutnya akan lebih efisien dari sisi ekonomi. Dengan demikian harga jualnya akan jauh lebih murah dan terjangkau namun tetap indah dan menarik.,

Tidak kenal maka tidak sayang, nampaknya ungkapan itu tidaklah berlebihan untuk mempromosikan suatu produk baru. Oleh karena itu untuk mensosialisasikan kepada konsumen maka promosi merupakan cara yang ampuh. Banyak cara untuk mengembangkan pemasaran suatu produk kain batik dan handycraft, antara lain dengan promosi langsung dan promosi tidak langsung. Pameran dan fashion show merupakan ajang promosi untuk mengembangkan suatu produk kain batik atau busana dari bahan batik. Pameran dan fashion show dapat mendatangkan banyak pengunjung dan biasanya merupakan konsumen yang memang tertarik didunia fashion. Oleh karena itu penyelenggaraannya harus dirancang yang cermat, pada even-even tertentu seperti menjelang hari raya, Natal dan Tahun baru atau pada momen-momen tertentu. Tempat penyelenggaraan pameran busana dan fashion show juga memegang peranan penting. yang penting harus diperhatikan siapa yang akan hadir, diundang, dan status sosial para undangan. Jenis busana atau jenis kain batik yang dipamerkan juga menentu- 
kan tempat penyelenggaraan pameran atau fashion show. Jumlah penonton sangat menentukan besar gedung yang dipilih. Dalam penelitihan ini momen pameran dirancang kerjasama dengan Pemda setempat dalam even Imogiri ekspo. Pameran tersebut dilaksanakan pada tanggal 14-19 Agustus 2009, karena Imogiri Ekspo merupakan pameran produk unggulan Kabupaten Bantul, maka pengunjung dari dalam dan luar Kabupaten pun banyak sekali yang berkunjung. Hal ini dapat dibuktikan dari dokumen buku tamu pada masing-masing stand pameran .

Sedangkan penyelenggaraan fashion show untuk memperkenalkan dan mempromosikan hasil pengembangan kain batik bantulan berpola dengan stilasi motif ethno modern dilaksanakan di Benteng Vedeburg dengan konsep out door agar pengunjungnya lebih banyak dan tidak terbatas.

\section{SIMPULAN}

Berdasarkan hasil penelitian dan pembahasan, dapat disimpulkan sebagai berikut: Berdasarkan analisis kebutuhan $100 \%$ pengrajin batik di dusun Giriloyo membutuhkan pelatihan pengembangan kain batik berpola dengan stilasi motif ethno modern dengan pewarnaan alam dan buku panduan praktis pengembangan motif batik ethno modern. Pengembangan batik ethno modern masih mengalami banyak hambatan. Hambatan tersebut antara lain para pengrajin kurang berani menginovasi motif batik dengan alasan takut "kualat", berbelum terbiasa dengan motif-motif yang modern.

Pengembangan kain batik dengan melakukan transformasi motif kain batik dengan stilasi motif ethno modern yaitu dengan menggabungkan motif tradisionil dengan motif modern menjadi motif baru tanpa mengubah makna dengan teknik transformasi.

Kain batik tulis bantulan berpola dengan stilasi ethno modern yang ditawarkan (8 model) dilihat dari segi bahan baku, motif batik, teknik pembatikan dan pewarnaan, penyajian, dan pengemasan, serta harga penjualannya dapat memuaskan konsumen, terbukti > dari 70\% konsumen menyatakan puas terhadap kain batik yang telah dibeli.

Pengembangan strategi pemasaran yang sangat dibutuhkan adalah program pameran, fashion show, leaflet, katu nama, pengemasan. Oleh karena itu pada penelitian ini dikembangkan juga program pameran dan fashion show. Karena pameran merupakan strategi yang mampu mendatangkan pengunjung. Sedangkan fashion show akan member kesempatan pada pengunjung khusus yang interes dalam bidang busana maupun batik.

Berdasarkan hasil yang diperoleh, dan untuk mencapai kesempurnaan pengembangan produk dan strategi pemasaran disarankan:

1. Dibutuhkan semangat dan keberanian untuk untuk terus melakukan inovasi. Oleh karena itu pengrajin perlu terus memompa semangat dan jangan pernah berhenti melakukan inovasi.

2. Membuka wawasan dengan banyak melihat referensi dan selera masyarakat terkini untuk menjadi sumber ide pengembangan motif.

3. Dilihat dari karakteristik usia konsumen yang paling banyak menyatakan sangat tertarik adalah konsumen dengan usia dewasa maka sebaiknya rancangan disain motif dibuat yang lebih elegan yaitu garis-garisnya simpel namun indah.

\section{DAFTAR PUSTAKA}

Agus Sachari, 2009. Makna Nilai Estetis Modern dalam Perkembangan Desain Abad Ke-20 di Indonesia

BBKB. (2000). Penerapan Hasil Litbang Pemakaian Zat Warna Non Karsin Zat Warna Alam pada Tekstil. Yogyakarta: Balai Besar Pengembanngan Kerajinan tekstil Batik Yogyakarta

BBKB. (2000). Penerapan Hasil Litbang Pemakaian Zat Warna Non Karsinogen dan Zat Warna Alam pada Tekstil. Yogyakarta: Balai Besar Pengembangan dan Kerajinan Tekstil Batik Yogyakarta.

Besar styoko. 2007. Program three in one (Training, certification, and placement) sebagai salah satu strategi penanggulan- 
gan pengangguran di Indonesia. Makalah seminar Nasional BLPT Yogyakarta.

Dibjo Hartono, 2009, Transformasi motif Tekstil,

Enny Zuhni Khayati, 2009, buku Panduan praktis penciptaan motif Batik Ethno modern

M. Hasanuddin, Widjiyati, dkk. (2001). Penerimaan Penerapan Zat Warna Alam dan
Kombinasinya pada Produk Batik dan Tekstil Kerajinan. Laporan Penelitian, Yogyakarta: BBKB.

Philip Khotler. (1997). Marketing Manajement, Analisis Perencanaan Implementasi dan Kontrol, Simon \& Schuster (Asia) Pltd. Sewan Susanto. (1980). Seni Kerajinan Batik Indonesia. Yogyakarta: BPBK. 